\title{
EFFECTS OF EL NIÑO ON THE COASTAL ECOSYSTEMS AND THEIR RELATED SERVICES
}

\author{
ROSSI, Sergio; ${ }^{\text {* }}$ SOARES, Marcelo de Oliveira ${ }^{\mathrm{b}}$
}

(a) Phd in Biological oceanography, Professor Universitat Autonoma de Barcelona (UAB). http://ictaweb.uab.cat/personal_detail.php?id=18

(b) Phd in Geosciences, Professor of the University Federal of Ceará (UFC). http://lattes.cnpq.br/0083585852610360

\section{(*) CORRESPONDING AUTHOR}

Address: University of Barcelona, Campus UAB s/n, Barcelona 08193, Spain., Tel: 935868647

E-mail: Sergio.Rossi@uab.cat

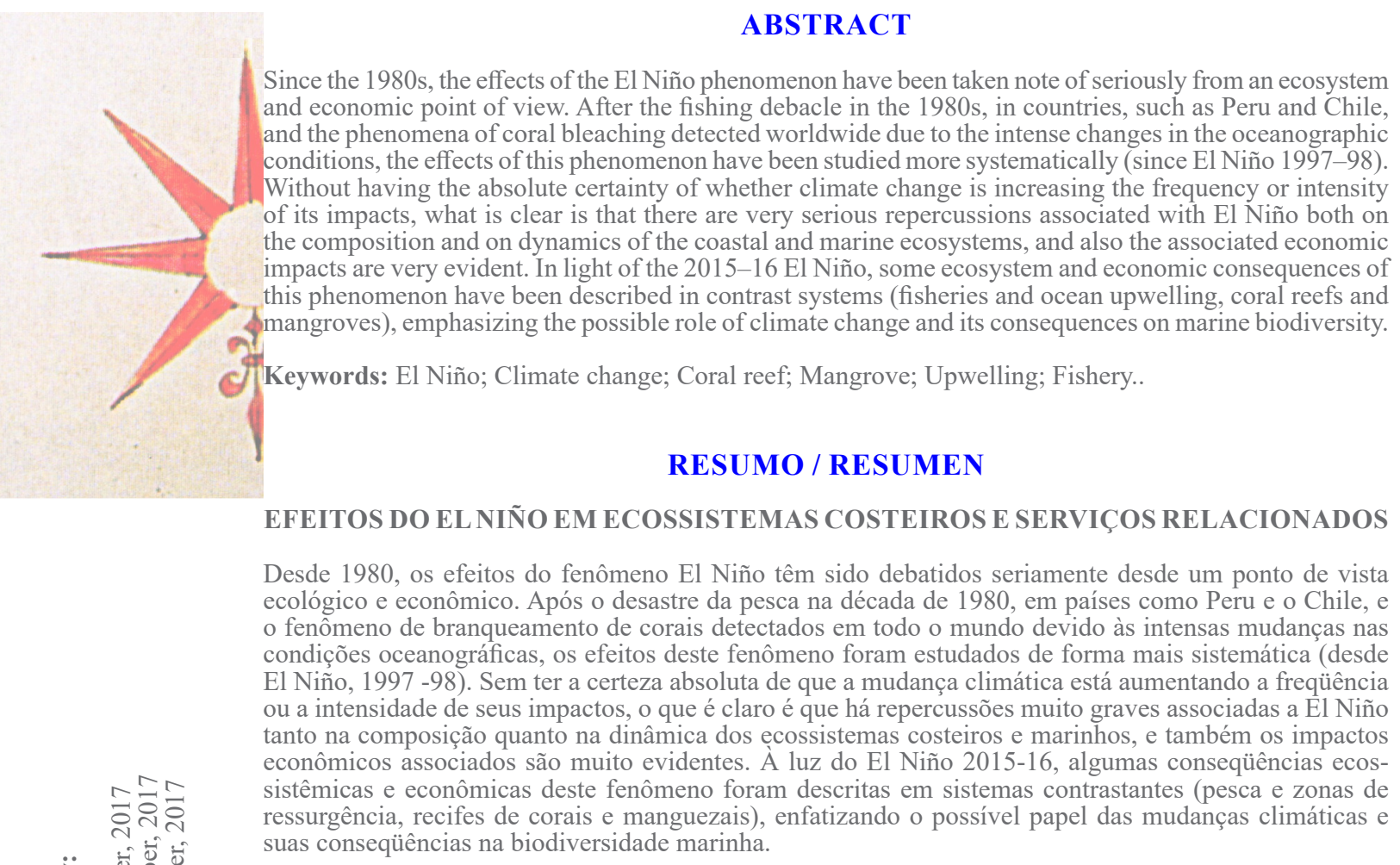

Palavras-chave: El Niño; Mudança Climática; Recife de coral; Manguezal; Ressurgência; Pesca.

\section{EFECTOS DEL EL NIÑO EN ECOSISTEMAS COSTEROS Y SERVICIOS RELACIONADOS}

Desde los años ' 80 del siglo pasado, los efectos del fenómeno de El Niño se han empezado a contabilizar de forma muy rigurosa desde un punto de vista ecosistémico y económico. Tras la debacle pesquera que sufrida por países como Perú o Chile durante los años ' 80 , o los fenómenos de blanqueo de coral detectados en diferentes partes del planeta debido a los intensos cambios de temperatura del agua y las condiciones oceanográficas, el efecto de este fenómeno se ha empezado a estudiar de forma más sistemática. Sin tener la certeza absoluta de si el cambio climático está incrementando frecuencia o intensidad de sus impactos, lo que está claro es que hay repercusiones muy graves tanto en la composición y funcionamiento de los ecosistemas como en los beneficios económicos que éstos reportan. En esta revisión, a la luz del último El Niño sufrido entre los años 2015 y 2016, se repasan algunas consecuencias ecosistémicas pero sobre todo económicas de dicho fenómeno, enfatizando el posible rol del cambio climático y sus consecuencias en las cadenas alimentarias marinas.

Palabras Clave:

Palabras clave: El Niño; Cambio Climático; Arrecife de coral; Manglar; Afloramiento; Pesca. 


\section{INTRODUCTION}

Centuries ago, Peruvian fishermen identified thermal anomalies in the coastal waters between December and March - an anomaly that transformed the ecosystems, thus, drastically reducing the catches of many fishes, crustaceans, and mollusks. This phenomenon was known as El Niño by the local people.

El Niño (austral summer during Christmas, hence the name) occurs when the strong winds that drag the coastal waters into the sea weaken, thus, allowing a band of large warm water, coming mainly from the zone of Indonesia, to be transported as a Kelvin wave. These waves are formed by a change in the water temperature that induces an imbalance (similar to a slope). The outcome of this is a massive displacement of water from one point to another, with the American continent being an obstacle. In other words, a gigantic current coming from the Western Pacific region collides with the coasts of Peru and Chile (Figure 1) (ARCOS et al. 2001; TRENBERTH 2013).

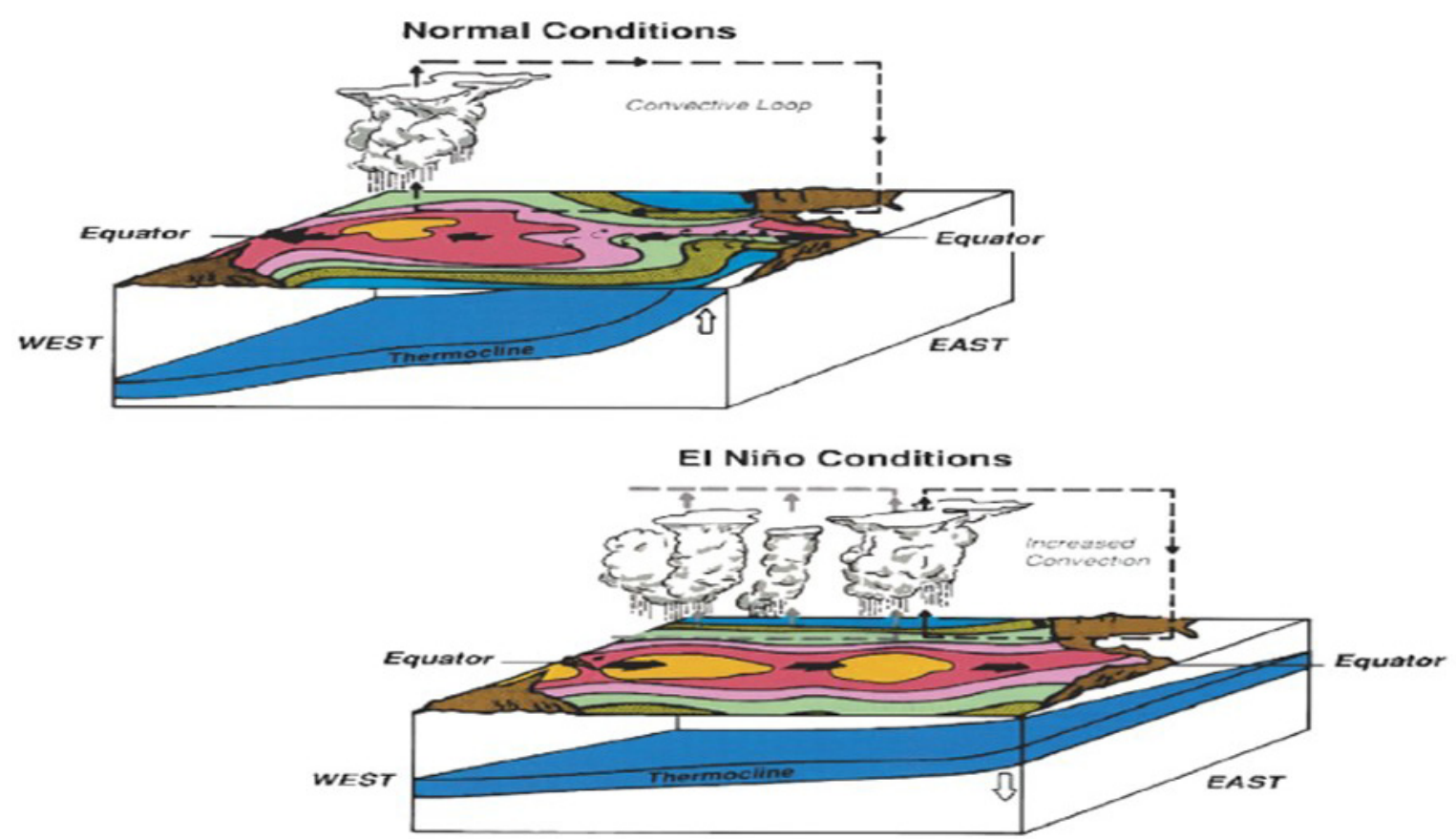

Figure 1 - El Niño phenomenon (from https:/www.pmel.noaa.gov/elnino/what-is-el-nino )

Under normal conditions, dry winds push warm surface waters from the coast in their direction of travel, thus, causing upwelling. During this, the cold waters of the deep ocean, rich in nutrients, replace the displaced surface water from the coast. The propagation and arrival of this Kelvin wave, comprising an immense mass of warm water (which can reach up to $8{ }^{\circ} \mathrm{C}$ above its average temperature) does not allow the deep waters to emerge to the surface, and therefore, the nutrients never reach the surface, as well (ARNTZ et al. 2006). The ecosystem stops being fertile, and the production of the system is transformed (ARCOS et al. 2001; ARNTZ et al. 2006; HARRISON \& CHIODI 2015).

This phenomenon leads to abnormally warm sea surface temperatures (SST) in the Pacific region. Further, this phenomenon is connected with major changes in the atmosphere through another process known as southern oscillation (SO). The link between these two processes leads to a whole new phenomenon, commonly known as El Niño Southern Oscillation (ENSO) (TRENBERTH 2013).

The ENSO phenomenon causes many ecological effects worldwide based on their location. Under ENSO, higher than normal pressures over the Philippines, Indonesia, Australia, and Southeast Asia causing drier conditions or even droughts (TRENBERTH 2013). This event can cause a dry climate in many parts of the world, such the islands of Hawaii, parts of Africa, Colombia, and the semiarid region of Brazil (BAUDOIN et al. 2017; BRITO et al. 2017; CORDOBA-MACHADO et 
al. 2015). In addition, excessive rains and floods occur in the Central and Eastern Pacific regions, west coast of the United States of America, and some parts of South America close to Argentina and Uruguay (WARD et al. 2016).

On the contrary, the phenomenon of La Niña has an opposite effect, and it is even less understood. A drastic drop in water temperatures can alter the ecosystem, as well as bringing about changes related to increased rainfall and drought (ARNTZ et al. 2006; TRENBERTH 2013). The invasion or displacement of species on this occasion is from the south to north, that is, from the polar climate toward higher latitudes (ARNTZ et al. 2006).

El Niño events have been observed since 1950. It occurred in 1951, 1953, 1957-58, 1963, 1965, 1969, 1972-73, 1976-77, 1982-83, 1986-87, 1990-95, 1997-98, 2002-03, 2004-05, 2006-07, 2009-10, and 2015-16. The El Niño events of 1997-98 and 2015-16 exhibited relatively high anomalies in the SST, and the retreat, on record, had major impacts on the dynamics and structure of the tropical and temperate ecosystems worldwide (TRENBERTH 2013; EDMUNDS 2017; HOEGH-GULDBERG et al. 2017; HUGHES et al. 2017).

Another recent effect of El Niño on the marine ecosystems is through the association between the recent global mean sea level (GMSL) changes and SST anomalies (HADDAD et al. 2013). This correlation between sea level changes and El Niño has been observed during three major El Niño events (1997-98, 2006-07, and 2009-10). The results revealed a number of oscillations in the GMSLs over short periods, suggesting that it is partly related to the El Niño effect.

Global changes associated with ENSO cause severe variations in the weather and climate around the coasts and oceans. Often, they have a profound impact on the biodiversity and humans, since floods, droughts, heat waves, and other shifts disrupt the ecosystem of the region. These environmental changes affect the global economy. The results indicated that Australia, Chile, Indonesia, India, Japan, New Zealand, and South Africa experienced a brief slowdown in their economic activity in response to El Niño shocks. However, other developed regions, such as the United States of America and Europe, manifested a growth-enhancing response (CASHIN et al. 2017).

Despite the advances in understanding the effects of El Niño on terrestrial ecosystems (HOLMGREN et al. 2001), its impacts on coastal and marine ecosystems are less known (see ARNTZ et al. 2006). In this study, we provide a short review on the effects of El Niño on the tropical and cold-temperate ecosystems (Figure 2). Further, we have provided case studies on the impacts on 1) fisheries and ocean upwelling, 2) coral reefs, and 3) mangrove ecosystems. Finally, we discuss perspectives on research in the coastal and marine ecosystems under stressful conditions induced by El Niño events.

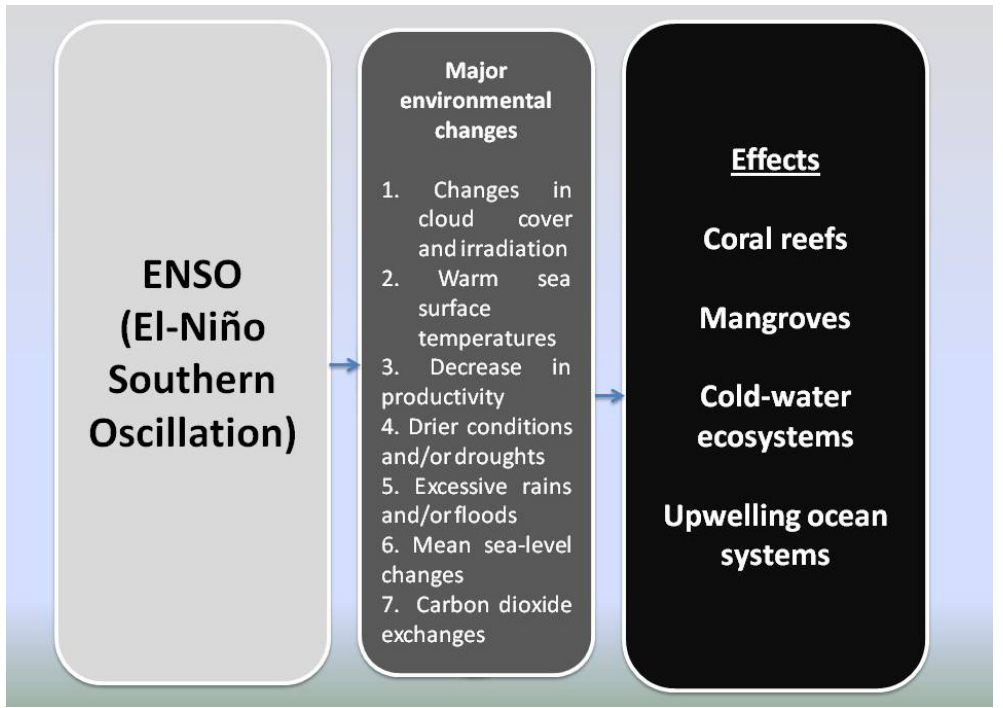

Figure 2 - Linking major environmental changes in the marine and coastal ecosystems with El Niño Southern Oscillation (ENSO). 


\section{COLD-TEMPERATE ECOSYSTEMS: FISHERIES AND OCEAN UPWELLING}

\section{EASTERN PACIFIC: THE HYPERPRODUCTIVE ZONE}

The South American Pacific Coast is one of the most productive areas of the world (ARCOS et al. 2001). Of the approximate eighty million tons of fish that are caught annually worldwide, about seven million tons (mean of 2003-12; in 2014, it dropped to three million) are the anchovetas (Engraulis ringens) (Figure 3) produced in these seas (mainly off the coast of Peru) (FAO 2016; HARRISON \& CHIOIDI 2015). This reveals the global importance of the cyclical disturbances, such as El Niño, which affects this and many other species.

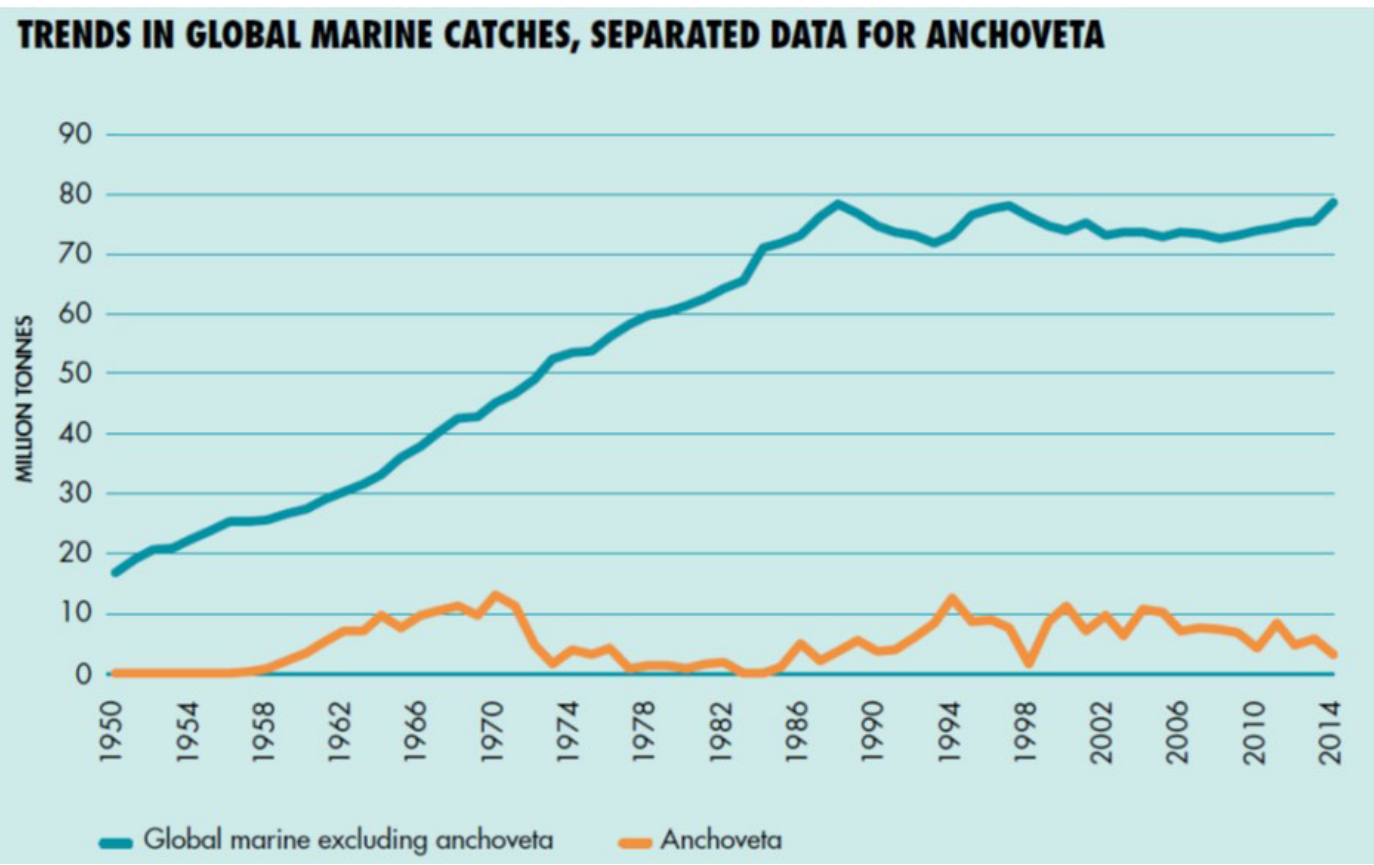

Figure 3 - Importance of Peruvian anchoveta (Engraulis ringens) in the overall World catch.

(Figure from FAO 2016).

Globally, the coastal zones of Northern Chile and Peru have the most productive aquatic ecosystems. The beaches here comprise innumerable shells, and remains of animal and plant species, which are evidences of the abundant underwater life that this ecosystem sustains (ARNTZ et al. 2006). This immense productivity is due to upwelling, that happened millions of years ago, when the South American continent was still drifting to its current position. The cliffs north of Antofagasta (Chile) have deposits of shells that are millions of years old (Figure 4).

In this coast (52 $\mathrm{m}$ above sea level), the horizontal layers of shells and conglomerate of sandstone fragments make a type of rock - clastic sedimentary rock. This structure was formed during the Pliocene epoch (5-2 million years ago), geological time of the Tertiary Era, during which the ice sheets of Antarctica were still forming and evolutionary history of the genus Homo had not yet started (ARNTZ \& FAHRBACH 1997). During the Pliocene epoch, along with the climatic oscillations at a global level and drifting of the South American platform occurred marine transgressions and regressions. These fluctuations in the sea level left behind large biogenic deposits as a record of intense ocean activity (Figure 4). The action of the sea today, as it happened millions of years ago, continues to incessantly deposit material, and mold and destroy the coast by erosion (ARNTZ \& FAHRBACH 1997). 


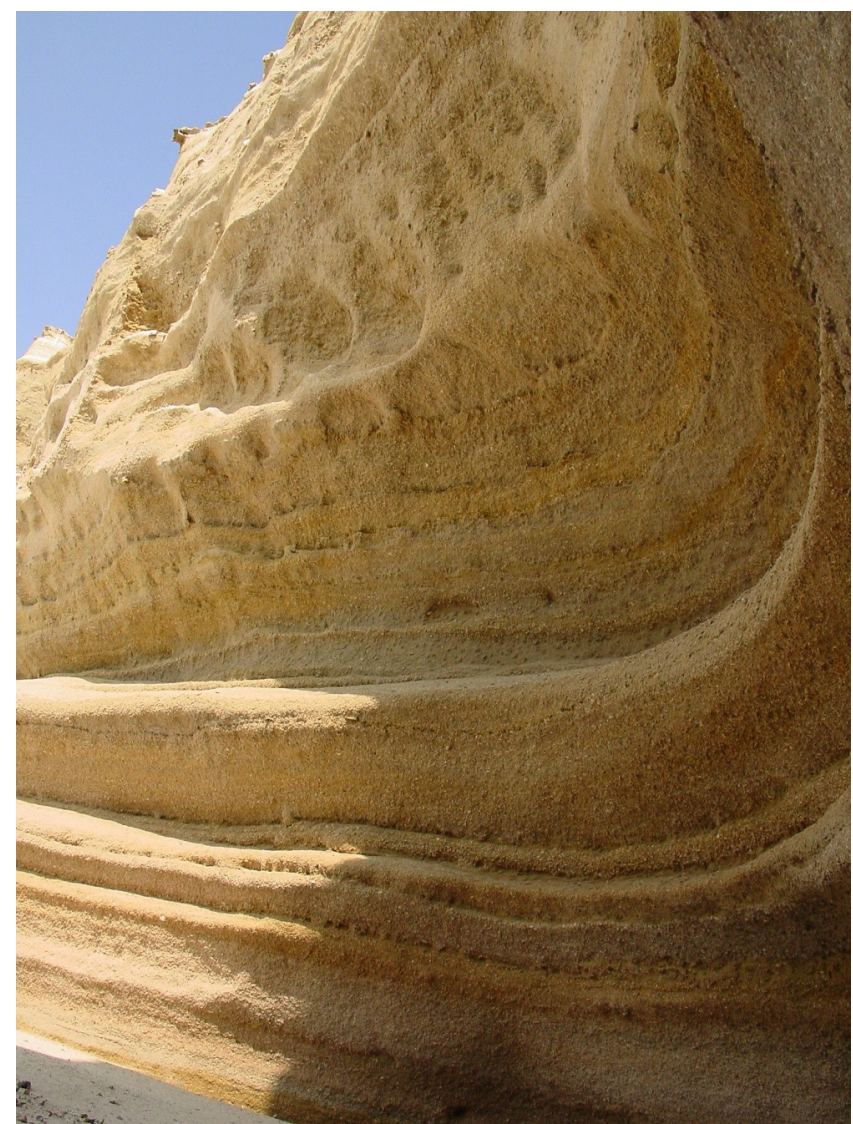

Figure 4. Coastal cliffs in the Antofagasta (Chile) region, showing the deposits of marine shells and other calcareous organisms (Photo credit Sergio Rossi).

However, this enormous productivity encounters moments of scarcity due to the El Niño phenomenon. The temperature change and, importantly, decline in the concentration of nutrients in the upwelling areas create a cascade effect transforming the productivity of ecosystems. Therefore, many species disappear or go down to their minimum production levels. In addition, the seas are tropicalized in a certain way, introducing many species from the north, that is, from the Pacific Central America and Colombia, during El Niño (ARNTZ \& FAHRBACH 1997; ARNTZ et al. 2006).

People, whose lives depend largely on the industrial and artisanal fishing, are accustomed to these effects. However, this is accompanied by long periods of hardship that, in reality, could be partially solved with policies based on scrupulous knowledge on the functioning of the ecosystem, with and without El Niño (FAO 2016). There are still many gaps in knowledge. Further, it is not well known how El Niño affects the ecological functioning of the coastal and marine ecosystems. In principle, organisms adapt to certain physical and chemical conditions in which they can eat, breathe, grow, and reproduce optimally. They can tolerate a certain margin of variability in parameters, such as oxygen concentration, salinity, and temperature (ROSSI et al. 2012). However, El Niño creates a very abrupt change in these, as well as other variables.

\section{COLLAPSE IN THE TROPHIC FLUX AND ARTISANAL FISHERIES}

On the coasts of the American Pacific, with El Niño, the warm water band coming from the southeastern Pacific region and lack of winds that displace the superficial water masses promote a convulsive effect on the ecosystem by increasing the water temperature and causing food deficiency to many species (ARNTZ et al. 2006). In fact, since the nutrients could not reach the surface in the Humboldt Current Upwelling made the algae, both microscopic and multicellular, lose the necessary base to maintain their reproduction rhythm. Thus, the rich waters lose their strength, and so does the organisms that depend on them (DIAZ \& MARKGRAF 2000). 
In rocky environments, many algae disappear, leaving the surface devoid of food for organisms, such as the sea urchins and fishes, that feed on them. Filter feeders, such as the bivalves and sea squirts, experience food collapse (microscopic algae), and also higher breathing rate (since, the water temperature is higher), thus consuming more energy. Therefore, they disappear en masse, leaving the underwater bed full of lifeless organisms (ARNTZ et al. 2006).

Many fishes migrate to the south of Chile, to colder waters, while other organisms that lack mobility perish or their numbers reduce drastically. Further, the recruitment of sessile animals, that live fixed to the substrate (be it rock or sand), can also decrease drastically in the affected areas (RIASCOS et al. 2017).

The organisms that depend on the fishes, crustaceans, and echinoderms for their sustenance, such as the birds and mammals, witness collapse of their food source (Figure 5). High mortality among the adults and new generations of sea lions, pelicans, and seagulls has been reported (ARNTZ \& FAHRBACH 1997).

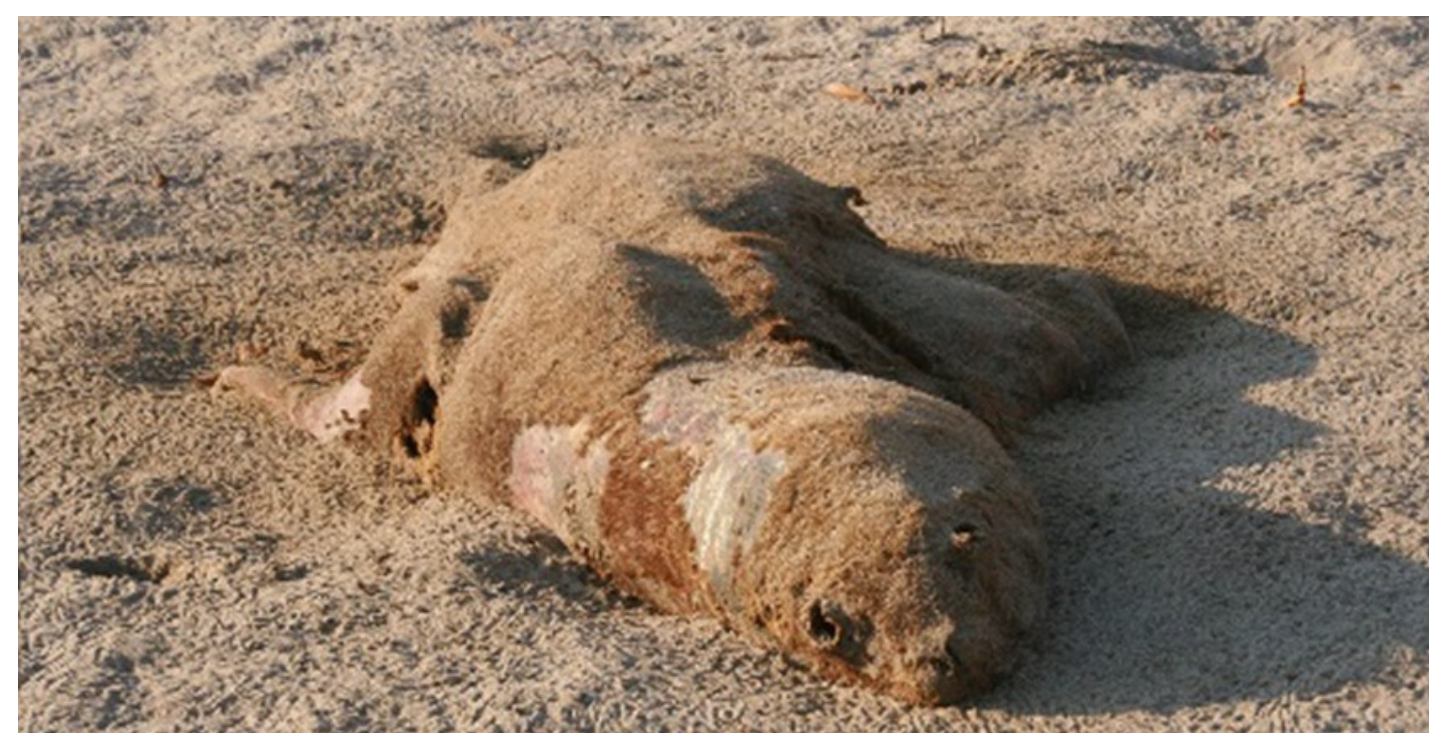

Figure 5 - A dead young sea lion on the beach in Chipana Bay (Iquique,

North Chile coast). (Photo credit Sergio Rossi).

As mentioned earlier, the El Niño related thermal anomaly and cascade of events it entails are recurrent. It happened regularly about forty thousand years ago (ARNTZ \& FAHRBACH 1997). It is estimated that every fifty years there is one El Niño event with high virulence. This was the situation in 1982 and 1983, years during which the anomaly was relatively high, causing serious damages. However, it has been reported that there are strong E1 Niños every 9 years (EDMUNDS 2017).

The frequency of El Niño is not well known. Trenberth et al. (2013) suggested that every three to seven years a severe warming of marine ecosystems occurs in the Tropical Pacific Ocean. This indicated that the entire economy based on fishing has to deal with the unpredictable oscillations that are known to occur.

In the alluvial zones, floods of up to $123 \mathrm{~m}$ with water speeds greater than $140 \mathrm{~km} \mathrm{~h}-1$ has been verified (SANDWEISS et al. 2004). This type of extreme weather phenomenon concentrates its power for a very short time in very limited spaces, where narrow basins meet high flows. Around every five hundred years, there is a Mega-Niño, capable of transforming the coastlines, causing prolonged droughts, thus influencing the survival of large human settlements due to famines and natural disasters (MEGGERS 1994).

El Niño significantly affects the economy of local fishing and agriculture. Further, it has been observed that when the phenomenon is virulent, its expansive waves can reach the entire planet. In Chile, Peru, and Ecuador, the repercussions on the gross domestic product reached up to $11-12 \%$, 
with a slow recovery in certain areas. For instance, in the anchoveta fishery, the catch reduced to less than a third of the normal level due to the ecosystem transformations that left the fishes without any food (ARNTZ \& FAHRBACH 1997). In 1982, the aftermath of El Niño was catastrophic, completely collapsing the fishing grounds and anchoveta fisheries. During the 1998 El Niño, the concerned authorities were much more prepared, therefore the fisheries adapted quickly to an expected biomass decline (BERTRAND et al. 2008).

Furthermore, in the coast of Chile and Peru, the jack mackerel (Trachurus symmetricus murphyi) fishery is one of the most important pelagic resources. The 1997-98 El Niño event caused remarkable shifts in the catches, where the juveniles dominated the fishing grounds. This might probably be due to the El Niño event affecting the feeding grounds of jack mackerel and migratory pathway of the juveniles (ARCOS et al. 2001). After this severe effect, the government, scientists, and fishing industry realized the importance to include the impacts associated with El Niño events in the planning and management of the fisheries present off the coast of Chile.

El Niño affects climate worldwide, particularly in tropical regions, where the developing countries are situated. The economy and its growth in these countries are vulnerable to climate related anomalies induced by El Niño. Recent studies suggested that the effect of El Niño is twice as large in the tropics when compared with that of the temperate areas, particularly in Africa and Asia Pacific. This is because agriculture and primary commodity exports, such as valuable commercial fishes, represent a major source of these economies (SMITH \& UBILAVA 2017).

If the impact of El Niño on this type of industrial fishing is serious, then its consequences on the small fishing consortiums at the foot of the coast in small towns are devastating. The lack of aquatic organisms, such as the macha (Mesodesma donacium), sea urchin (Loxechinus albus), and crabs (genus Cancer), including fishes makes the lives of the people very difficult (ARNTZ et al. 2006). They lead their lives in precarious conditions without running water, electricity, and efficient sanitary system. These conditions are perfect for epidemics, such as dysentery, cholera, and dengue, after heavy rains in the area.

It is estimated that during the E1 Niño events in 1997 and 1998, around twenty-five thousand people died directly due to floods, droughts, storm surges, and strong winds. In addition, more than one hundred million people were affected by other factors. Around six million relocated because of the disasters caused by the violent weather on the unprepared infrastructures. The direct economic losses were estimated for the first time, rigorously, in 1997-98. The economic loss was estimated to be 34,000 million dollars, leaving the economies of the most affected countries in a very difficult situation. (RODÓ et al. 2002; SUN et al. 2006). More recently, in South Africa, the strong El Niño of 2016 caused severe drought leading to negative impacts on the economy and livelihood. This led to a discussion on the effectiveness of disaster risk reduction strategies (BAUDOIN et al. 2017).

After decades of adaptation to the phenomenon, the populations in these areas have adapted to a certain extent to the strong conditions imposed by this tremendous energy pulse that bursts into the system. The studies carried out during 2000-10 gave more reliable data on the capture and density of fishes, which is very useful while formulating the anchovy management models based on the intensity of El Niño. Further, the data on precipitation, temperature, wave height, and ocean currents are used to understand the effects of El Niño on the coastal dynamics, especially its impacts on the marine biodiversity (DONNER et al. 2017).

\section{COLD WATERS: BIVALVES AS INDICATORS}

The production of bivalves and other mollusks is crucial for the local economies. However, the impact of El Niño on mollusks is devastating, especially in semi-enclosed systems, such as bays.

Under normal conditions, the high primary production is one of the factors that gives rise to oxycline from a depth of $60-80 \mathrm{~m}$. The large amount of organic matter produced during this process in the water column falls to the bottom, where they degrade, and consume the dissolved oxygen 
(ROSSI et al. 2012). From that depth, further down the water column becomes hypoxic or anoxic affecting the life forms present in this region. The organisms, such as bivalves, that need oxygen to survive, disappear.

However, when there is an El Niño, the production in the column and the oxycline moves to deeper places. Therefore, it is assumed that the bivalves can occupy more space and proliferate in deeper places. However, this is not the case observed. The main problem detected is that the increase in temperature affects the physiology of bivalves. It has been found that, especially in Peru, the tolerance of bivalves to changes in temperature is limited leading to its disappearance (ARNTZ et al. 2006). However, this is not the only contributing factor. Another important factor is the quantity and quality of the food. Therefore, detailed studies on these and other ecological factors might provide insights on the local disappearance of the macha in many management areas after the strong El Niño events of 1982 and 1983. Further, the space left empty by the macha was occupied shortly after by the other apparently similar species, the machita (Donax marincovichi) (ARNTZ et al. 2006). This further emphasizes the importance of the use of biological and ecological data while managing and regulating any resource.

\section{TROPICAL ECOSYSTEMS: CORAL REEFS AND MANGROVES}

\section{EL NIÑO AND CORAL REEFS}

On the other side of the Pacific, where the Kelvin waves generate, in the coral reefs of Australia, Papua, and Indonesia, also suffer the consequences of over warming of water (HUGHES et al. 2017). This increase in temperature causes the bleaching of many species (BIANCHI et al. 2017). Bleaching resulted in the expulsion of the algae Symbiodinium by the organisms that they lived in symbiosis, because of the increase in temperature making the conditions unfavorable for the host (IGLESIAS-PRIETO et al. 1992). The mechanisms of bleaching refer to the entire set of processes that lead to individual and large-scale coral bleaching events.

There is mounting evidence on multiple ways the thermal stress affects the host and its endosymbionts. Once bleached, the recovery of the species may be relatively slow or may not happen at all, leaving the organism without the adequate energy resources to survive (Figure 6) (EAKIN et al. 2010).

The consequences of El Niño on ecosystem functioning in general are very vast. One of the most serious consequences is the loss of the structures that harbor the diverse coral reefs. The animal forests (living 3-D structures comprising suspension feeding animals, such as corals, gorgonians, and sponges (ROSSI 2013) is a fundamental part of the entire ecosystem functioning. Their disappearance is disastrous for most of the sessile organisms and associated mobile species, such as the fishes (BIANCHI et al. 2017).

In recent years (2015-16), the tropical oceans have experienced anomalous SST causing a global episode of coral bleaching and their unprecedented mortality (Figure 7). The El Niño event of 2015-16 is third on the global scale of strong events since 1980. Hughes et al. (2017) examined this event in multiple dimensions in the Great Barrier Reef (Australia) and compared the results with the El Niño events of 1998 and 2002. The research indicated that bleaching in 1998 and 2002 did not lessen the impact of the El Niño event in 2015-16 on coral bleaching and mortality. The El Niño event of 2015-16 is considered the longest coral bleaching event recorded globally. 


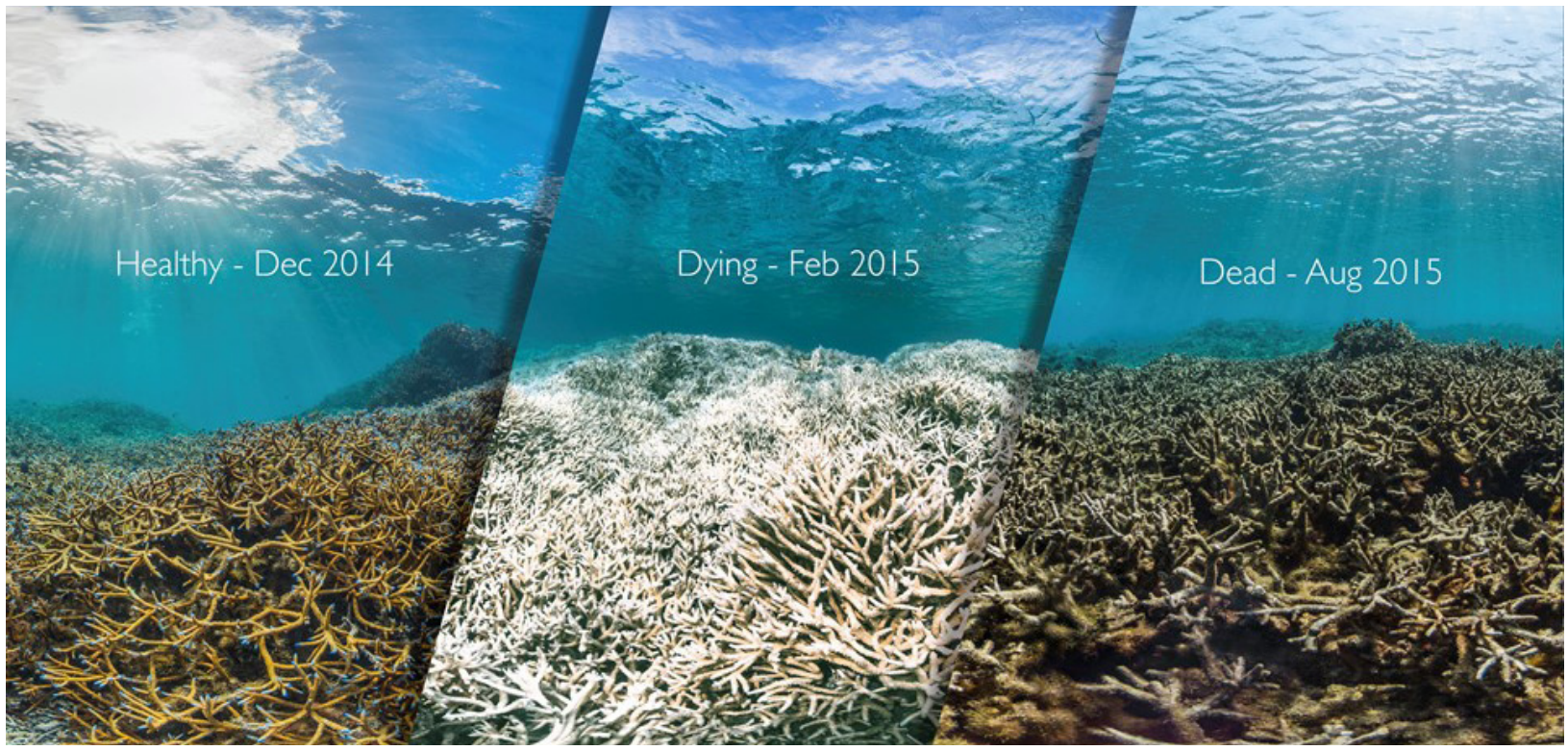

Figure 6 - Bleaching event in the Australian Great Barrier. Once bleached, the reefs lose their capacity to withstand, therefore the biodiversity is lost, and the productivity drops. The massive phenomenon of bleaching becomes more intense and frequent as the temperature of the sea rises. (Picture from http://www.desdemonadespair.net/2016/03/

great-barrier-reef-coral-bleaching-at.html).

2015 Oct 6 NOAA Coral Reef Watch 60\% Probability Coral Bleaching Thermal Stress for Feb-May 2016

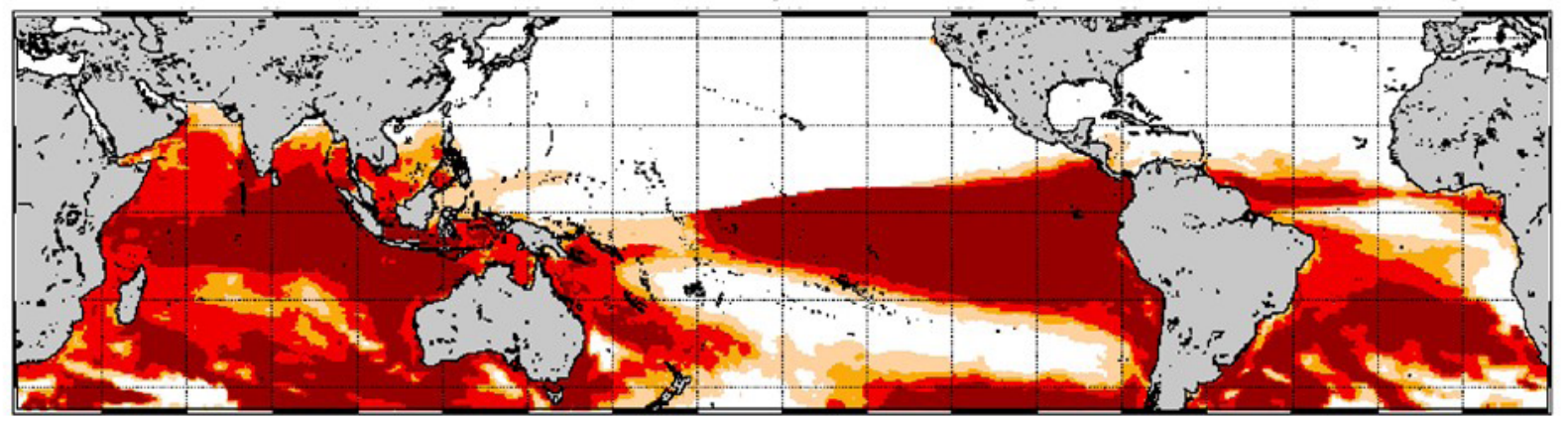

Potential Stress Level:

Warning

Alert Level 1

Alert Level 2

Figure 7- In October 2016, the National Oceanic and Atmospheric Administration (NOAA) issued a general bleaching alert based on the El Niño related warming evidence. (Photo credit NOAA). 
The global warming (MORA et al. 2013) and intense El Niño (2015-16) probably together prolonged the exposure of reef-building corals to warm waters. The coral bleaching was observed in the Western Pacific Ocean in mid-2014 (EDMUNDS 2017). In October 2015, El Niño affected the SST and prolonged the mass coral bleaching event (Figure 7). This hypothesis is supported by the relatively long El Niño events during which the corals are exposed to relatively high SST. The increase in the degree of heating weeks (DHWs) poses a huge problem while conserving coral reefs, which leads to a decline in the coral reef health.

In 2016, 31\% of the tropical reefs in the Great Barrier Reef experienced 8-16 DHWs (HUGUES et al. 2017), this being up to four times higher than those of the reefs that were severely affected ( $>60 \%$ bleached) during the previous El Niño episodes. Studies have demonstrated that the water quality and pressure from fisheries had no effect on the development of the bleaching phenomenon. Further, local conservation measures were not enough to preserve these complex structures alive (HUGHES et al. 2017). This might be because of a cumulative effect of the low growth capacity of many reef-building coral species, and more frequent and intense bleaching events. Furthermore, some vulnerable key species do not have enough time to recover (HOEGH-GULDBERG et al. 2017).

It is important to understand that El Niño is not the only stressor responsible for coral bleaching, because many such events across the world occur without the El Niño related anomalies. Local and global anthropogenic factors, such as overfishing, diseases, sedimentation, pollution, storms, El Niño, La Niña, and climate change, can together or individually create stressful conditions to disrupt the symbiosis between the corals and Symbiodinium spp. As mentioned earlier, Hughes et al. (2017) indicated that even the reefs with low anthropogenic impacts (pristine and protected) are susceptible to warm waters, as revealed by the El Niño event of 2015-16. The rising temperatures will transform coral reefs into new configurations (simple and less diverse) (HOEGH-GULDBERG et al. 2007; HOEGH-GULDBERG et al. 2017), which will have serious repercussions on the goods and environmental services provided by these marine ecosystems. These services include coastal protection, ocean recreation, tourism, biogeochemical cycles, and nursery effect.

Global warming and many anthropogenic factors affected the coral reefs in the Anthropocene (HOEGH-GULDBERG et al. 2007), mainly through two mechanisms (BOSEC \& MUMBY 2015). A chronic mechanism, due to rising temperatures in the 21 st century, decreases coral calcification resulting in reduced somatic growth. An acute mechanism, observed during El Niño events, brings about coral bleaching and causes high mortality, when sea temperatures become anomalously high.

Bosec and Mumby (2015) indicated that acute mechanisms have a great overall impact. However, the nature of the synergistic effect with chronic stress depends on the metric considered. Chronic and acute stresses act additively on the reef ecosystem. They form a powerful synergy while influencing the resilience of tropical reefs globally. It has been demonstrated that, after the E1 Niño 1997-98 bleaching, the species cover and other parameters may recover completely in 16 years. However, the ecosystem functioning and biodiversity may never recover (BIANCHI et al. 2017). Some species just disappear, and the phase shift left may completely transform the species composition of very large areas. Thus, changing the trophic chain, energy fluxes, and balance between mixotrophic and heterotrophic organisms (BIANCHI et al. 2017).

\section{ECOLOGICAL INDICATORS: CORALS AND MANGROVES}

An important aspect that has to be investigated in relation to the effects of El Niño in tropical marine environments is identifying indicators for monitoring climate oscillations and ecosystem impacts. The coral skeletons retain records of past oceanographic conditions, therefore can be studied using isotopes. These isotopic records can highlight multidecadal climate variability of the locality. Pereira et al. (2015) detected changes in the isotopes of the coral colonies in South Atlantic region due to the 2009-10 El Niño event; a recognized period of widespread coral bleaching. Such 
proxies are useful detectors of anomalous climatic fluctuations and links between thermal stress and El Niño events in the oceans.

The evidence connecting the marine ecosystems and indicators of El Niño events are commonly related to the Pacific and Indian Oceans and represent direct ecosystem response (such as coral bleaching due to warm waters) to El Niño. However, the high SST recorded in several parts of the world during El Niño events are commonly linked to coral bleaching and mortality in other parts of the world, such as the South Atlantic Ocean. Ferreira et al. (2013) examined coral bleaching in the oceanic islands of the Southwestern Atlantic region and analyzed their association with the anomalous SST. The study revealed that in situ temperature anomaly during the 2009-10 El Niño event was similar to that of the 1997-98 event. This explained similar bleaching intensity. These events are related to anomalies in SST, including several weeks of above average temperatures, and positive hot-spot values.

Recent findings suggested some indirect effects of El Niño on the tropical marine ecosystems using indicators. The El Niño effect can cause abrupt regional meteorological changes in some parts of the tropical Southwestern Atlantic region. A decrease in cloud cover and rainfall, followed by increased irradiation and anomalous SST can affect coral growth (EVANGELISTA et al. 2007) and mortality of bryozoans (KELMO et al. 2004).

In the Pacific and Indian oceans, the impacts of El Niño on the ecosystems have been quantified in different ways. Even before the direct impacts of El Niño on the coral reefs, Ampou et al (2017) observed a massive mortality of corals in Indonesia due to a rapid fall in the sea level. The study stressed that such drops in the sea level had vast effects on the coral reef resilience. Further, these effects may have been strengthened by the warm waters caused by El Niño (AMPOU et al. 2017). The recurrence of El Niño, as mentioned earlier, is not clear in terms of its periodicity, however its effects are strong (DONNER et al. 2017; HUGHES et al. 2017). The rise in water temperatures may lead to a shift in predator abundance, such as crown starfish, adding pressure on an already unstable environment (ERIKSSON et al. 2017). A rapid response by the authorities in terms of fishing and habitat conservation, adapting to the needs of the new situation, is essential to recover the populations. Eriksson et al. (2017) pointed that the local needs and socio-economic framework have to be considered while formulating the conservation measures, adopting political measures of management and conservation to a fast-changing environment. Unfortunately, most of the people living in these areas have already resigned to the fact that these catastrophic events are a part of their lives ("we rebuild and move on", ERIKSSON et al. 2017).

Coral reefs are deeply affected by El Niño; however, there could be some triggering factors influencing the spawn of some coral species. In Mo'orea, Edmunds (2017) found a massive larval recruitment in the coral reefs during the 2015-16 El Niño event. The study demonstrated that long-time monitoring is essential to understand the real changes and impacts of El Niño on the reef community. This is because, comparisons between recruitments can be made only if the previous data on it are available. Similarly, Bianchi et al. (2017) demonstrated a differential recruitment and survival of young corals in Maldives after the 1998 El Niño. Being the dominant species, the corals replaced the other species which have not only different taxonomical and biological characteristics, but also different functional properties from an eco-engineering point of view.

One of the least investigated aspects of global environmental change is the effects of El Niño on the mangrove ecosystems (WARD et al. 2016; JENNERJAHN et al. 2017). The mangroves provide important goods and services to people, mainly in the tropical coasts (COSTANZA et al. 2014). Floods and droughts commonly control the estuarine water flow, growth of mangrove forests, salinity, and transfer of material from the mainland to the sea. Recent reviews (MARENGO \& ESPINOZA 2016; MARENGO et al. 2017) have anticipated shifts in the rainfall pattern induced by El Niño and La Niña in the tropical semiarid coasts, including Northeast Brazil. Further, floods and droughts are also expected that can affect the transitional ecosystems, such as the mangroves. Shifts 
in salinity, organic matter, contaminants, and nutrients induced by extreme floods and droughts have drastic effects on mangroves (PEREIRA et al. 2013; COSTA et al. 2016; SLOTERDIJK et al. 2017).

One of the important effects of El Niño on the mangroves is its impact on the hydrological events that drive the dynamics of the aquatic ecosystems. Several extreme hydrological events have been reported in the Amazon region in the last decade. Some of these either intensified or reduced rainfalls, and the subsequent floods and droughts were associated with La Niña and El Niño events, respectively. Among the periods of drought in the Amazon region, 1982, 1983, and 1997-98 were related to El Niño (MARENGO \& ESPINOZA 2016), while the wet years were related to La Niña. However, El Niño and La Niña are not the only factors of climate anomalies that affect estuarine ecosystems in the Amazon region, considering that the anomalous warm waters in the tropical North Atlantic region was due to other important factors.

During La Niña, the Amazon coast experienced high rainfall that exacerbated the normal hydrological and hydrodynamic values. The anomalies in rainfall induced lower salinity (minimal of 5), more turbidity, and higher dissolved nutrients and phytoplankton biomass in the waters when compared with that of the normal conditions without the influence of La Niña (PEREIRA et al. 2013).

In the Amazon coast, the ecology of estuaries with large mangrove forests was affected by the droughts caused by El Niño. During severe drought periods, higher than normal salinity occurred mainly during the dry season (COSTA et al. 2016). Reduced rainfall decrease the fluvial contribution to the ocean and increase the salinity of estuaries located in the tropical coasts of Africa, Australia, and Brazil.

Arid and semiarid coasts occur on both sides of the South Atlantic region (Brazil and Africa). These regions are prone to droughts induced by El Niño events and other climate anomalies (BRITO et al. 2017; MARENGO et al. 2017). The local factors (such as, multiple dams) and global anomalies affect these freshwater deprived estuaries, including the gradient of salinity. The estuaries of this region exhibit hypersalinity (higher than that of the sea). Mangroves are essential estuarine habitats considering their nursery effect and high productivity. Hypersalinity can reduce the freshwater species population, which get substituted by marine fish larvae (SLOTERDIJK et al. 2017) in the coasts affected by severe droughts, with repercussions on the economies of small-scale fisheries.

Another neglected aspect of El Niño on mangroves is the association between these climate anomalies and the mangrove expansion. Studies conducted in Mexico (LÓPEZ-MEDELLÍN et al. 2011) and New Zealand (LOVELOCK et al. 2007, 2010) revealed that the El Niño events are associated with mangrove expansion along the new coastlines. A 20\% expansion in mangroves was found on Baja California (Pacific coast of Mexico). This landward expansion of mangrove forests was pronounced during the El Niño events. In New Zealand, Lovelock et al. (2007) demonstrated that the high fertilization and sedimentation rate induced by an El Niño event caused an increase in the mangrove area. Further, Lovelock et al. (2010) evaluated 50 years of mangrove area data, and found a general pattern of seaward migration of the plants. Moreover, high rate of mangrove expansion was correlated to El Niño events.

Mangroves are an essential part of the lives of many people of the region, not only because of their economic dependence but also because of their way of life (WARD et al. 2016; QUEIROZ et al. 2017). Thus, to the already ongoing mangrove degradation due to the direct impacts of factors, such as aquaculture (POLIDORO et al. 2010; QUEIROZ et al. 2013), the El Niño effect may lead to a less biodiverse and more stressed ecosystem.

These environmental effects and scenarios associated with El Niño should be studied further in some of the neglected tropical ecosystems, such as the Atlantic coral reefs and mangroves. The cumulative impacts of global change (acidification, sea surface temperature, and rainfall anomalies) and local impacts (overfishing, urbanization, and pollution) in tropical ecosystems are some of the most important research aspects that must be developed in the future. 


\section{FINAL CONSIDERATIONS}

This review indicated that an extreme El Niño plays a major role in the temperate and tropical marine ecosystems, and economies that depend on the goods and services of the oceans worldwide. The recent El Niño event (2015-16) was one of the strongest since the first recorded event. There are increasing scientific evidences that link El Niño events and global climate change. Strategies of adaptation against climate change can be ineffective if an extreme El Niño threatens the ecological functioning and biodiversity of the coastal and marine ecosystems. We discussed some evidences that revealed the impacts of El Niño on the upwelling in the pelagic ecosystems, mangroves, and coral reefs. It is important to gain knowledge on the impacts of El Niño on pelagic and benthic habitats to contribute to a better understanding of resilience of these ecosystems, and the goods and services they provide. This approach can assist the mitigation and adaptation strategies against El Niño episodes in the future.

The services provided by these complex and biodiverse ecosystems may drastically change in the coming decades due to this recurrent phenomenon. Therefore, better quantification of the ecosystem services that cannot be valued directly with an economic approach is necessary (PAOLI et al. 2017). The El Niño episodes play an important role in regulating the biogeochemical cycles, including modulating carbon dioxide exchanges between the ocean and atmosphere (HOLMGREN et al. 2001). This phenomenon influences the frequency of fires in terrestrial ecosystems, which result in more carbon dioxide (CO2) emission. Moreover, changing rainfall patterns and temperatures on land through teleconnections can enhance $\mathrm{CO} 2$ uptake by the terrestrial biosphere (TRENBERTH 2013). However, the effects of El Niño on marine ecosystems worldwide and its consequences on $\mathrm{CO} 2$ cycle are poorly understood. An important perspective to future research is to understand the role of El Niño in marine biogeochemical cycles and resilience of coastal and marine ecosystems against a possible increase in the occurrence of El Niño in the coming decades. Thus, there is an urgent need to address this complex puzzle to formulate better management and conservation strategies to increase the resilience of the three different ecosystems - cold-temperate upwelling areas, coral reefs, and mangroves — threatened by different synergistic impacts.

\section{ACKNOWLEDGEMENTS}

SR was funded by Marie Curie International Outgoing Fellowship (ANIMAL FOREST HEALTH, Grant Agreement Number 327845) and a Marie Curie COFUND grant (P-Sphere COFUND, UAB, European Commission). MOS would like to thank CNPQ (Process 400916/2016-9), PRONEX FUNCAP/CNPq (Geodiversidades, Interações e Impactos Socioambientais) and INCT AmbTropic (CNPq/CAPES/FABESB). Authors want to thank the support of the Generalitat de Catalunya to MERS (2014 SGR - 1356). This work is contributing to the ICTA "Unit of Excellence" (MinECo, MDM2015-0552).

\section{BIBLIOGRAPHIC REFERENCE}

AMPOU, E.E.; JOHAN, O.; MENKES, C.E.; NIÑO, F.; BIROL, F.; OUILLON, S.; ANDRÉFOUET, S. Coral mortality induced by the 2015-2016 El-Niño in Indonesia: the effect of rapid sea level fall. Biogeosciences, v.14, p.817-826, 2017.

ARCOS, D.F.; CUBILLOS, L.A.; NÚÑEZ, S.P. The Jack mackerel fishery and El Niño 1997-1998 effects off Chile. Progress in Oceanography, v.49, p. 597-617, 2001.

ARNTZ, W.E.; FAHRBACH, E. EI Niño: experimento climático de la naturaleza. Causas físicas y efectos biológicos. Fondo de Cultura Economica, 312p. 1997. 
ARNTZ, W.E.; GALLARDO, V.A.; GUTIÉRREZ, et al. El Niño and similar perturbation effects on the benthos of the Humboldt, California, and Benguela current upwelling ecosystems. Advances in Geosciences, v. 6, p.243-265, 2006.

BAUDOIN, M.A.; VOGEL, C.; NORTJE, K.; NAI, M. Living with drought in South Africa: lessons learnt from the recent El Niño drought period. International Journal of Disaster Risk Reduction, v. 23, p.128137, 2017.

BERTRAND, S.; DEWITTE, B.; TAM, J.; DÍAZ, E.; BERTRAND, A. Impacts of Kelvin wave forcing in the Peru Humboldt Current System: Scenarios of spatial reorganizations from physics to fishers. Progress in Oceanography, v. 79, n. 2-4, p. 278-289, 2008.

BIANCHI, C.K.; MORRI, C.; LASAGNA, R.; MONTEFALCONE, M.; GATTI, G.; PARRAVICINI, V.; ROVERE, A. Resilience of the marine animal Forest: Lessons from Maldivian Coral reefs after the mass mortality of 1998. In: Rossi,S et al. (eds). Marine animal forests: The ecology of Benthic Biodiversity Hotspots, pp.1241-1269, 2017.

BOZEC, Y.M.; MUMBY, P.J. Synergistic impacts of global warming on coral reef resilience. Philosophical Transactions of the Royal Society B, v.370, p. 20130267, 2015.

BRITO, S. S. B.; CUNHA, A. P. M. A.; CUNNINGHAM, C. C.; ALVAlÁ, R. C.; MARENGO, J. A.; CARVALHO, M. A. Frequency, duration and severity of drought in the Semiarid Northeast Brazil region. International Journal of Climatology, v. 23, p. 200-213, 2017

CASHIN, P.; MOHADDES, K.; RAISSI, M. Fair weather or foul? The macroeconomic effects of El Niño Journal of International Economics, v.106, p. 37-54, 2017.

CÓRDOBA-MACHADO, S.; PALOMINO-LEMUS, R.; GÁMIZ-FORTIS, S.R.; CASTRO-DÍEZ, Y.; ESTEBAN-PARRA, M.J. Assessing the impact of El Niño Modoki on seasonal precipitation in Colombia. Global and Planetary Change, v.124, p. 41-61, 2015.

COSTA, A.K.R.; PEREIRA, L.C.C.; COSTA, S.F.S.; LEITE, N.R.; FLORES-MONTES, M.; COSTA, R.M. Spatiotemporal variation in salinity during drought years in an Amazonian estuary (Taperaçu). Journal of Coastal Research, v.75, n.1, p.48-52, 2016.

COSTANZA， R.; de GROOT, R.; SUTTON, P.; PLOEG, S.V.D.; ANDERSON, S.J.; KUBISZEWSKI, I.; FARBER, S.; TURNER, R.K. Changes in the global value of ecosystem services. Global environmental change, v.26, p. 152-158, 2014.

DÍAZ, H.; MARKGRAF, V. (Eds.) EI Niño and the Southern Oscillation: multiscale variability and global and regional impacts, Cambridge Univ. Press, 496 pp., 2000.

EAKIN, C.M.; MORGAN, J.A.; HERON, S.F.; SMITH, T.B.; LIU G.; ALVAREZ-FILIP, L.; BACA, B.; BARTELS, E.; BASTIDAS, C.; BOUCHON, C, et al. Caribbean corals in crisis: record thermal stress, bleaching, and mortality in 2005. PloS One, v.5,p. e13969, 2010.

EDMUNDS, P.J. Unusually high coral recruitment during the 2016 El Niño in Mo'orea, French Polynesia. Plos One, v. 12, n.10, e0185167. https://doi.org/10.1371/journal.pone.0185167

ERIKSSON, H.; ALBERT, J.; ALBERT, S.; WARREN, R.; PAKOA, K.; ANDREW, N. The role of fish and fisheries in recovering from natural hazards: Lessons learned from Vanuatu. Environmental Science and Policy, v. 76, p.50-58, 2017

EVANGELISTA H.; GODIVA, D.; SIFEDDINE, A.; LEÃO, Z. M. A. N.; RIGOZO, N. R.; SEGAL, B.; KEMPEL, M.; KIKUCHI, R. K. P.; CORNEC, F. L. Evidences Linking ENSO and Coral Growth in the Southwestern-South Atlantic. Climate Dynamics, v.29, p. 869-880, 2007.

FAO. The state of World Fisheries and Aquaculture: Contributing to food security and nutrition for all. Rome. 200p. 2016.

FERREIRA, B. P.; COSTA, M.B.S.F.; COXEY, M.S.; GASPAR, A.L.B.; VELEDA, D.; ARAUJO, M. The effects of sea surface temperature anomalies on oceanic coral reef systems in the southwestern tropical Atlantic. Coral Reefs, v.32, p. 441-454, 2013.

HADDAD, M.; TAIBI, H.; AREZKI, S.M.M. On the recent global mean sea level changes: Trend extraction and El Niño's impact. Comptes Rendus Geoscience, v.345, n.4, p. 167-175, 2013. 
HARRISON, D.E.; CHIODI, A.M. Multi-decadal variability and trends in the El Niño-Southern Oscillation and tropical Pacific fisheries implications. Deep Sea Research Part II: Topical Studies in Oceanography, v. 113, p. 9-21, 2015.

HOEGH-GULDBERG, O.; MUMBY, P.J.; HOOTEN, A.J.; STENECK, R.S.; GREENFIELD, P.; GOMEZ, E.; HARVELL, C.D.; SALE, P.F.; EDWARDS, A.J.; CALDEIRA, K.; KNOWLTON, N.; EAKIN, C.M.; HUGHES, T.P.; BARNES, M.L.; BELLWOOD, D.R.; CINNER, J.E.; CUMMING, G.S.; JACKSON, J.B.C.; KLEYPAS, J.; LEEMPUT, I.A.V.; LOUGH, J.M.; MORRISON, T.H.; PALUMBI, S.R.; NES, E.V.; SCHEFFER, M. Coral reefs in the Anthropocene. Nature, v. 546, p. 82-90, 2017.

HUGHES, T.P. et al. Global warming and recurrent mass bleaching of corals. Nature, v. 543, p.373-377, 2017. HOLMGREN, M.; SCHEFFER, M.; EZCURRA, E.; GUTIÉRREZ, J.R.; MOHREN, G.M.J. El Niño effects on the dynamics of terrestrial ecosystems. Trends in Ecology \& Evolution, v.16, n.2, p.89-94, 2001.

IGLESIAS-PRIETO, R.; MATTA, J.L.; ROBINS, W.A.; TRENCH, R.K. Photosynthetic response to elevated temperature in the symbiotic dinoflagellate Symbiodinium microadriaticum in culture. PNAS, v. 89, n. 21, p. 10302-10305, 1992.

JENNERJAHN, T.C.; GILMAN, E.; KRAUSS, K.W.; LACERDA L.D.; NORDHAUS, I.; WOLANSKI, E. Mangrove Ecosystems under Climate Change. In: Rivera-Monroy V., Lee S., Kristensen E., Twilley R. (eds) Mangrove Ecosystems: A Global Biogeographic Perspective. Springer, Cham, p.211-214, 2017.

KELMO, F.; ATTRILL, M.; GOMES, R.C.T.; JONES, M.B. El Niño induced extinction of coral reef bryozoan species from Northern Bahia, Brazil. Biol Conserv, v.118, n.5, p.609-617, 2004.

LÓPEZ-MEDELLÍN, X.; EZCURRA, E.; GONZÁLEZ-ABRAHAM, C.; HAK, K.; SANTIAGO, L.S.; SICKMAN, K.O. Oceanographic anomalies and sea-level rise drive mangrove inland in the Pacific coast of Mexico. Journal of Vegetation Science, v.22, p.143-151, 2011.

LOVELOCK, C.E.; FELLER, I.C.; ELLIS, J.; SCHWARZ, A.M.; HANCOCK, N.; NICHOLS, P.; SORRELL, $B$, Mangrove growth in New Zealand estuaries: the role of nutrient enrichment at sites with contrasting rates of sedimentation. Oecologia, v. 153, p. 633-641, 2007.

LOVELOCK, C.E.; SORRELL, B.K.; HANCOCK, N.; HUA, Q.; SWALES, A, Mangrove forest and soil development on a rapidly accreting shore in New Zealand. Ecosystems, v. 13, p. 437-451, 2010.

MARENGO, J.A.; TORRES, R.R.; ALVES, L.M. Drought in Northeast Brazil-past, present, and future. Theoretical and Applied Climatology, v. 20, p. 1-12, 2017.

MARENGO, J. A.; ESPINOZA, J. C. Extreme seasonal droughts and floods in Amazonia: causes, trends and impacts. International Journal of Climatology, v. 36, n.3, p. 1033-1050, 2016.

MEGGERS, B.J. Archeological evidence for the impact of mega-Niño events on Amazonia during the past millennia. Climatic change, v. 28, n.4, p. 321-338, 1994.

MORA, C.; FRAZIER, A.G.; TONG, E.J.; LONGMAN, R.J.; KAISER, L.R.; DACKS, R.S.; WALTON, M.M.; FERNANDEZ-SILVA, I.; STENDER, Y.O.; ANDERSON, J.M.; SANCHEZ, J.J.; AMBROSINO, C.M.; GIUSEFFI, L.M.; GIAMBELLUCA, T.W. The projected timing of climate departure from recent variability. Nature, v.502, p. 183-187, 2013.

PAOLI, C.; MONTEFALCONE, M.; MORRI, C.; VASSALLO, P.; BIANCHI, C.K. Ecosystem functions and Services of the Marine Animal forests. In: Rossi,S et al. (eds). Marine animal forests: The ecology of Benthic Biodiversity Hotspots, pp.1271-1312, 2017. Doi: 10.1007/978-3-319-17001-5_35-1,

PEREIRA, L.C.; OLIVEIRA, S.M.; COSTA, R.M.; COSTA, K.; VILA-CONCEJO, A. What happens on an equatorial beach on the Amazon coast when La Niña occurs during the rainy season? Estuarine, Coastal and Shelf Science, v.135, p. 116-127, 2013.

PEREIRA, N.S.; SIAL, A.N.; KIKUCHI, R.K.P.; FERREIRA, V.P.; ULLMANN, C.V.; FREI, R.; CUNHA, A.M.C. Coral-based climate records from tropical South Atlantic: 2009/2010 ENSO event in C and O isotopes from Porites corals (Rocas Atoll, Brazil). Annals of Brazilian Academy of Sciences, v.87, n.4, p. 1939-1957, 2015.

POLIDORO, B.A et al. The loss of species: Mangrove extinction risk and geographic areas of global concern. PLoS ONE, v. 5, n.4, p. e10095, 2010. Doi: 10.1371/journal.pone.0010095 
QUEIROZ, L.; ROSSI, S.; MEIRELES, J.; COELHO, C. Shrimp aquaculture in the federal state of Ceará, 1970-2012: Trends after mangrove forest privatization in Brazil. Ocean \& Coastal Management, v. 73, p. 54, 2013.

QUEIROZ, L.S.; ROSSI, S.; CALVET-MIR, L.; RUIZ-MALLÉN, I .; GARCÍA-BETORZ, S.; SALV-PRAT, J.; MEIRELES, A.JA. Neglected ecosystem services: Highlighting the socio-cultural perception of mangroves in decision-making processes. Ecosystem Services, v. 26, p. 137-145, 2017.

RIASCOS, J.M.; SOLÍS, M.A.; PACHECO, A.S.; BALLESTEROS, M. Breaking out of the comfort zone: E1 Niño-Southern Oscillation as a driver of trophic flows in a benthic consumer of the Humboldt Current Ecosystem. Proceedings of Biological Sciences, v.28, n.1857, 2017. Doi: 10.1098/rspb.2017.0923

RODÓ, X.; PASCUAL, M.; FUCHS, G.; FARUQUE, A.S.G. ENSO and cholera: A nonstationary link related to climate change? PNAS, v. 99, n.20, p. 12901-12906, 2002.

ROSSI, S.; BRAMANTI L.; BROGLIO E.; GILI J.M. Trophic impact of long-lived species indicated by population dynamics in the short-lived hydrozoan Eudendrium racemosum. Marine Ecology-Progress Series. v. 467, p. 97-111, 2012.

ROSSI, S. The destruction of the "animal forests" in the oceans: Towards an over-simplification of the benthic ecosystems. Ocean and coastal management, v. 84, p. 77-85, 2013.

SANDWEISS, D.H.; MAASCH, K.A.; CHAI, F.; ANDRUS, C.F.T.; REITZ, E.J. Geoarcheological evidence for multidecadal natural climatic variability and ancient Peruvian fisheries. Quaternary Research, v. 61, n.3, p. 330-334, 2004.

SMITH, S.C.; UBILAVA, D. The El Niño Southern Oscillation and economic growth in the developing world. Global Environmental Change, v.45, p.151-164, 2017.

SLOTERDIJK, H.; BREHMER, P.; SADIO, O.; DORING, J.; EKAU, W. Composition and structure of the larval fish community related to environmental parameters in a tropical estuary impacted by climate change. Estuarine, Coastal and Shelf Science, v. 197, p. 10-26, 2017.

SUN, C.H.; CHIANG, FS.; TSOA, E.; CHEN, M.H. The effects of El Niño on the mackerel purse-seine fishery harvests in Taiwan: An analysis integrating the barometric readings and sea surface temperature. Ecological Economics, v. 56, n. 2, p.268-279, 2006.

TRENBERTH, K.E. El Niño Southern Oscillation (ENSO). Reference module in Earth Sciences and Environmental Sciences. Elsevier, p. 1-12, 2013.

WARD, P.J.; KUMMU, M.; LALL, U. Flood frequencies and durations and their response to El Niño Southern Oscillation: Global analysis. Journal of Hydrology, v.539, p.358-378, 2016.

WARD, R.D.; FRIESS, D.A.; DAY, R.H.; MACKENSIE, R.A. Impacts of climate change on mangrove ecosystems: a region by region overview. Ecosystem Health and Sustainability, v.2, n.4, p.1-25, 2016. 